imofurschung, 1941,6:150-17\%

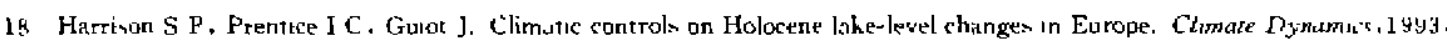
8. $189-2 ? 10$

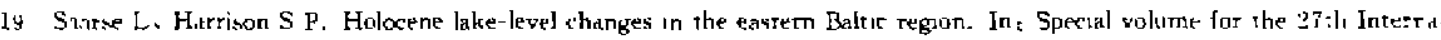
ronal Ceugraphical Congrus, $M$ an and Nezture 1992,01$\}, 6-2 n$

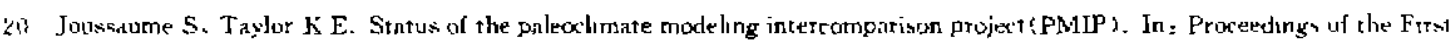
Internatiwnal AMIP Sctentifi, Conference, WCRP Report, 1995,92,425-43n

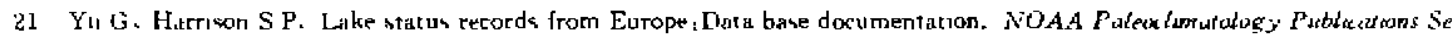
res. Report. 1495. 3:1-451

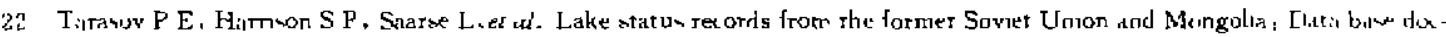

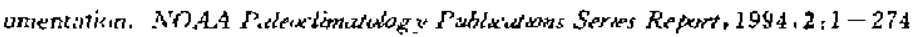

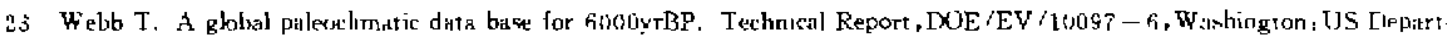
mnt of Energy, 1985. 155

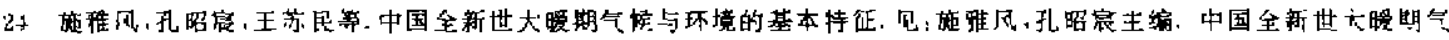

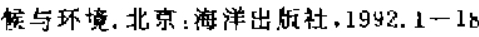

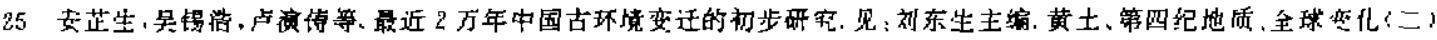
北京: 科学出版社、1990.1-26

26 Hartson S P,Kutzbach J E,Prentice IC, et di. The response of northern hemisphere extra tropical clemate and vegetatian to urbetally-induced changes in insolation during the last interglactal: results of atmospherie genetal cirrulation model ant bi, smearmulations. Quateratary Requarch, 1995,43; i i4-184

\title{
STUDIES ON GLOBAL LATE QUATERNARY LAKE-LEVEL DATA BASES
}

\author{
Ge Yu

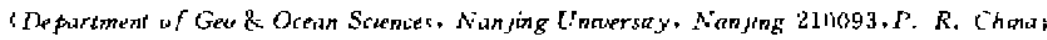

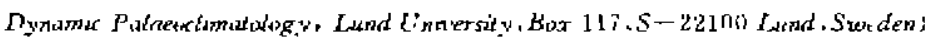

\begin{abstract}
Fluctuations of lake status reflect changes in water balance of precipitation minus evaporation $(P-E)$ over a catchment. The ancient lake status can provide information of precipitation and humidity durıng the late Quaternary. Synchronous changes in regional lake status may keep lake levels from being influenced by non-climatic factors or local factors. The recognition that lake data could be used to reconstruct past regional chmate changes leads to the construction of atobal lake-level data base. Nowadays, Quaternary lake status data bases have played a key rnle in reconstructions of continental-scale atmospheric circulation patterns and are used to compare and evaluate the simulations of precipitation and $P-E$ from the atmospheric general circulation mod els.

Lake records from North Eurasia show regionally-coherent patterns of changes during the late Quaternary, Lakes, peripheral to the Scandinavian ice sheet, were lower than today at the glacial maxımum. but high in the Meditertanean zone . reflecting the dominance of glacial anti-
\end{abstract}


cyclonic conditions in North Europe and a southward shift of the westerlies. The influence if the glacial anticyclonic circulation attenuated in the late glacial period, and the westerlies gradually shifted northward, so that drier conditions in south of the ice sheet were confined to a progressively narrower zone in North Europe, and the Mediterranean zone became drier. During the Holocene. there was a gradual shift to conditions wetter than present in central Asia. associated with the expanded Asian monsoon, and in the Mediterranean, in response to a local, monsoontype circulation. Conditions were drier in North Europe, reflecting the increased incidence of blocking anticyclones centred on Scandinavia. Conditions in the interior of North Eurasia were similar or slightly wetter than present. likely associated with cyclonic activity on the downstream limb of the summer anticyclone in the west and monsoon penetration in the east. These reflect thechanges in insolation and glacial boundary conditions.

Simulations of the response to insolation forcing at 6000 yrBP made with five different AGCMs show some common features. e. g. more humid than tociay in the mid-latitudes of Eurasian continent, enhancement of the Afro-Asian monsoons. drier conditions in North Europe but wetter conditions in the Mediterraneanregion. By comparing the lake data with simulated $P$ - $E$ fields basis can be provided forunderstanding the observed climattc changes and for evaluating the climate model simulations.

Thus the paper introduced the work on European lake status database and discussed the basis. methods and applications of the data bases. in order to improve work on the Chunese data base and speed the global data base.

Key Words Late Quaternary lake-level, the data base. Eurasian continent

\section{图 版 说 明}

图版 I 不同的大气环流模型对 $6 \mathrm{kaBP}$ 的 $P-E$ 模损与湖泊水位的相对现代变化的对比图.上：欧共体汉堡 模型(ECHAM 第 3.2 版); 中: 美国国家大气研究中心的气模模型(CCM 第2 版); 下: 法国气候与环 境模型站楳型 (LMCE 第 4 胶)。楳型资料来源 Yu 和 Harrison ${ }^{2101}$.

Plate 1 6kaBP comparison map between the $P-E$ fields of different GCMs and the lake data. The $P-E$ values are present by their differences at 6 ka from the present (6-oka). Upper: Model ECHAM; Middle: Model CCM: Lower; Model LMCE. Modelling data from Yu and Harison $1: 1$.

图饭 I 不同的大气环流模型对 $6 \mathrm{kaBP}$ 模拟的 $P-E$ 与湖泊水位的相对现代变化的对比图续图版 1 1, 上: 英国大学大气模型计划模型(UGAMP 第 2.0版)，中：英国气象局模型(UKMO 第 3.2 版)，图例与

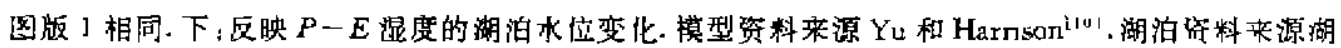
泊数据库 $13.21 .2 \times$,

Plate I 6kaBP comparison map between the $P-E$ fields of different GCMs and the lake data Plate I continued '. Both $P-E$ values and lake status are present by their differences at 6 ka from the present ( 6 oka s. Upper: Model UGAMP; Middle; Model UKMO. Keys as the Plate I, Lower; lake data, Modelling data from Yu and Harison ${ }^{125}$ and lake data from the data bases $13.21,2.2$. 
湖泊

第 9 第 3 期 1997 年 9 月
学治月河，

湖泊
粉据/死

活船，

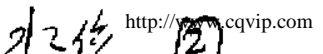

$01-210$ JOLRNAL OF LAKE SCIENCES

\title{
末次盛冰期以来全球湿润状况的地质证据 全球古湖泊数据库及其湖水位变化的大尺度时空分析

\author{
秦伯强 \\ (中国科学院南京地理与湖泊研究所、南京 210608 )
S. P. Harrison
于草
P. E. Tarasov
IDynamks Palaewhintology Group, Lund Univerkity, Lund. Sweden) \\ Harr, Sp
}

\begin{abstract}
提要价绍了正在建设中的全球湖泊数据库的情况，以及该数据库的水位资料所反映的晚 更新世末期以来全球湿润状况的变化.通过大尺度湖水位变化的时空分析.结果显示当含湖泊水 位状志较历史时期而言,位于低纬干旱或半干旱地区的湖泊水位较低,而中纬及高纬湿润地区的 湖泊水位较高. 自末次冰盛期以来,北美大陆中南部地区湖泪水位自高至低,反映出该地区气候条 件由湿变干.至早、中全新世达最干㫗、而在非洲及南亚季风地区、冷期偏干、瞹期偏湿. 特别是在 早、中全新世的温暧时期, 为历史上最湿润时期. 北半球中纬度地带的气候干湿变化与北半球冰盖 的存在及其消融导致的西风带的南北摆动有关、而北半球季风区在早、中全新世出现的高湖面与 北半球夏季辐射的增加有密切联系.
\end{abstract}

关链词全球湖泊数据库 湖水位高低 时空分柿

湖泊是一定区域内的蓄水体、其水位的变化及水体的大小反映湖盆内的湿润状况，天然 条件下的湖泊水位变化可以发生在不同的时间尺度上,小到月际、年际.大到百年、千年尺度. 而湖泊变化的信息则是通过湖盆地貌、沉抧物的岩性、狍粉、藻类及生物类型而保存下来. 如沉 积相中的纹泥反映的是湖水位的月际变化-而且是一种深水沉积环境、但颗粒较粗、层理较差 的沉积物反映的是一种滨湖或浅水区的沉积环境等. 这些是用于定量确定古湖水位高低的物 理基础.

影响湖面变化的因素很多,如地质构造、冰川消长及对湖泊的补给、自然冲淤和人类活动 等.当这些因子被排除之后.湖泊水位的变化主要受气候条件的控制.内陆湖泊的水位变化已 被公认为气候变化敏感的指示器. 但吞吐湖泊的水位消长由于受出流的影响而不及内陆湖泊 那样对气候变化敏感. 当湖盆内来水量增加时.增加的水量一部分用于增加出流、另一部分用 于抬高湖水位. 在此情形下, 吞吐湖的水位变化尽管不如内陆湖盆那样敏感。但也能部分地反 映流域内湿润状况的变化. 因此.无论是内陆湖还是吞吐湖都可以成为指示湖盆内湿润状况的 指示器. 由于湖泊水位变化反映的是湖区水量负亏与入流径流之间的平衡, 也就是反映了湖盆 内湿润状况与热量条件之间的平衡, 即降水与蒸发之差, 或称之为有效降水.

以上述思想为指导而开展的湖泊数据库的工作, 其目的是为了考察历史时期不同时间及

- 㷡共体科学基金会得助项目.

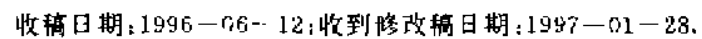


空间范围内某一地区乃至全球范围内的湿润状況的变化及其在大范围内, 或称大陆尺度上的 变化模式. 这项工作始自 70 年代.以牛津湖泊水位数据库 (OLLDB $)^{[1]}$ 最为著称. 该湖泊水位 数据库以干早或半干早地区内陆湖泊为主. 在此之后, 又陆续建立了欧洲湖泊数据库 $(\text { ELSDB })^{[2]}$ 、前苏联及蒙古地区湖泊水位数据库 (FSUDB $)^{[9]}$ ，中国湖泊水位数据库

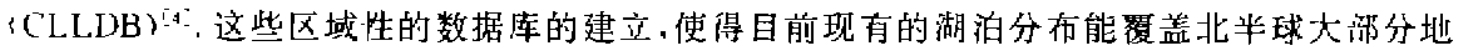
区. 所含的湖泊类型不仅有封闭湖，还有吞吐湖. 所有湖泊水位记录均排除了非气候因子的影 响. 尽管各个地区性的湖泊数据库仍在建设中, 但已足以组成一个全球性的湖泊水位变化数据 库、并由此提供一个全球性的有关湿润条件变化的大尺度时空分析与综合.

\section{I 全球湖泊水位变化资料的综合与全球湖泊水位变化数据库}

由上球各个区域湖泊数据库提供的湖泊水位资料产生的全球湖泊数据库、目前已拥有 677 个湖泊. 这些湖泊大多分布在北半球中、低纬地区(图 1)、其中有68个来自原苏联攻蒙古 地区的湖泊数据库 (FSUDB); 118 个来自欧洲湖泊数据库(ELSDB): 124 个来自中国湖泊数据 库(CLLDB)：38 个来自更新的非洲湖泊数据库 (ALSDB)；其余的 329 个来自牛津湖泊数据库 (OLLDB). 由于各个地区性数据库的结构在许多方面不一致, 为此全球湖泊水位数据库建立 时采取了统一的标准. 如取 1000 年为一个间隔.到 $30 \mathrm{kaBP}$ 截止. 以 $1 、 2 、 3$ 来表示水位的低、 中、高. 这 3 级水位的频率划分, 在各个地区性湖泊数据库保持其原有的划分方案, 即在4 津数 据库及中国湖泊数据库中, 分别以频率 $15 \%, 15^{\circ}-70 \%$ 及 $70 \%$ \% $-104 \%$ 划分湖水位的低、

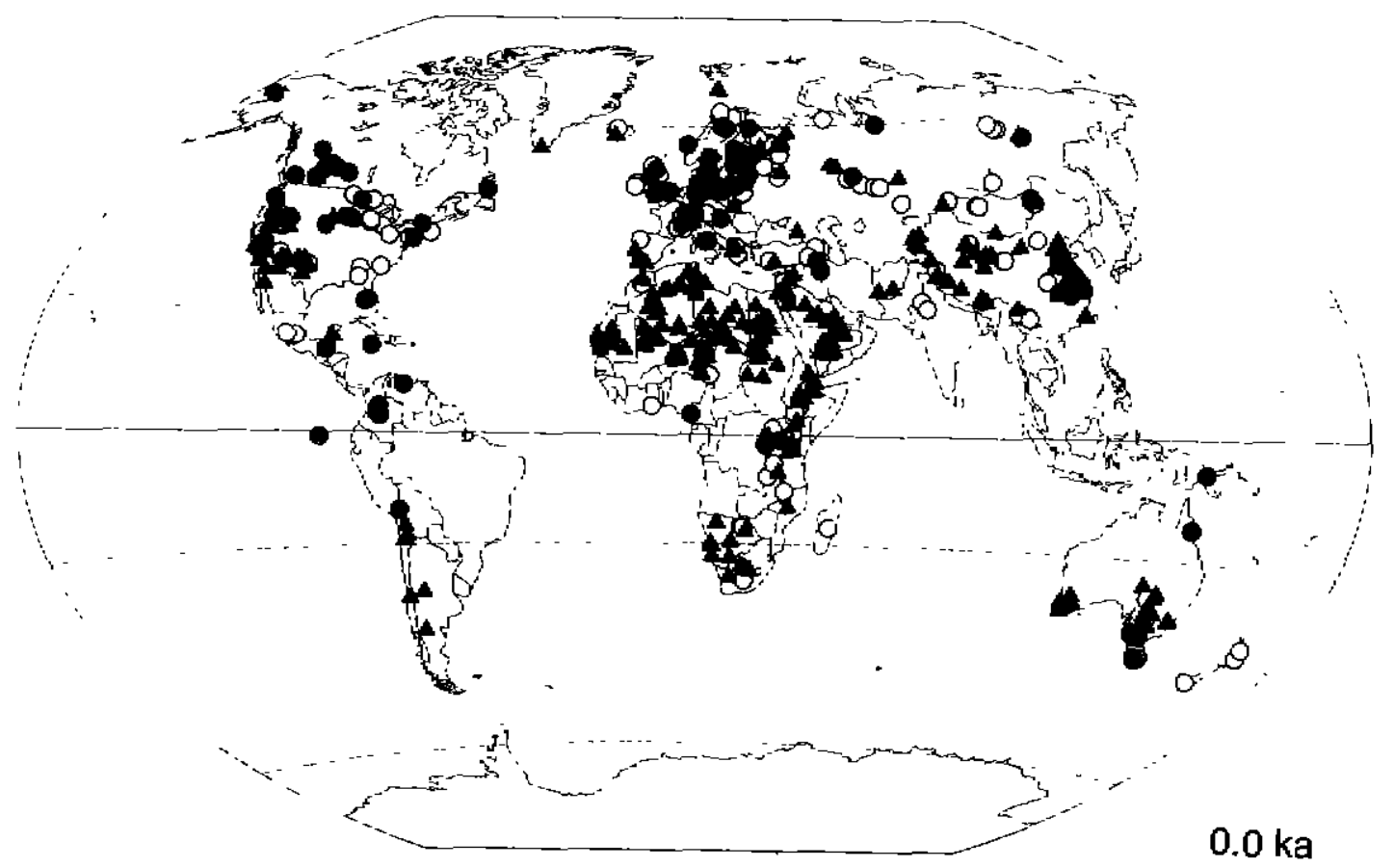

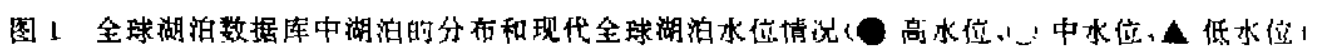

Fig. I The lake sites distribution from Global Lake Status Data Base and global lake status of ( $\mathrm{kaBP}\left(\mathrm{High}, \mathrm{I}_{-}^{-}\right.$: Intermediate. $\boldsymbol{A}$ Low) 


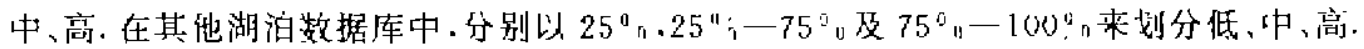

在数据库的建设中, 评价某一时段上湖触水拉记录的测年的精度也很重要. 对于一个这续 站孔柱反映的湖水位变化序列.由于其测年点分布不均匀.相邻两个测年点控制的时段有长有 短，鼠然如果内插出来的某一时段的湖水位记录泭近有 ${ }^{1} \mathrm{C}$ 浦年资料作参比，则其年代精度较 高. 反之则低. 为此用 7 级来来评价其定年的好坏 ${ }^{[5}$. 在最后进行时空综合分析时, 住往会有个 別点的变化情况与相邻湖泊点位不协调。这时首先应查该点的测年精度如何. 由于部分地区性 湖泊数据库中缺乏测年的精度评价，在全球湖泊水位数据库建立时给出了所有湖泊点位的年 代精度评价.

\section{2 晚更新世末期以来全球湖泊水位变化揭示的湿度变化 大尺度时空综合分析}

对于某一特定时段,湖水拉与现在相比,比现在高意味着当时的水分条件比现在湿润,反 之比现在干旱. 按湖水位的高、中、低分别赋值为 $3 、 2 、 1$, 这样、两个时段湖水位之差, 就成为一 $2 、-1 ， 0 、 1 、 2$. 分别表示很干、干、无变化、湿、很湿. 图 1 为现在湖泊水位状况.可以看出, 在中、 低线干旱与半干旱地区、包括北美洲西南部、非洲大陆及阿拉伯半帛.亚洲大部及澳大利亚南 部、湖泊水位较低、而在中、高纬地区、北美洲中部以北。欧洲大部地区及亚洲北部, 水位较高。 这与当今全球的湿润状況是一致的.

图 2 为 $18 \mathrm{kaBP}$ 时的湖水位与现在水位之差. 可以看仙, 在欧洲中、高纬地区、气候似平比

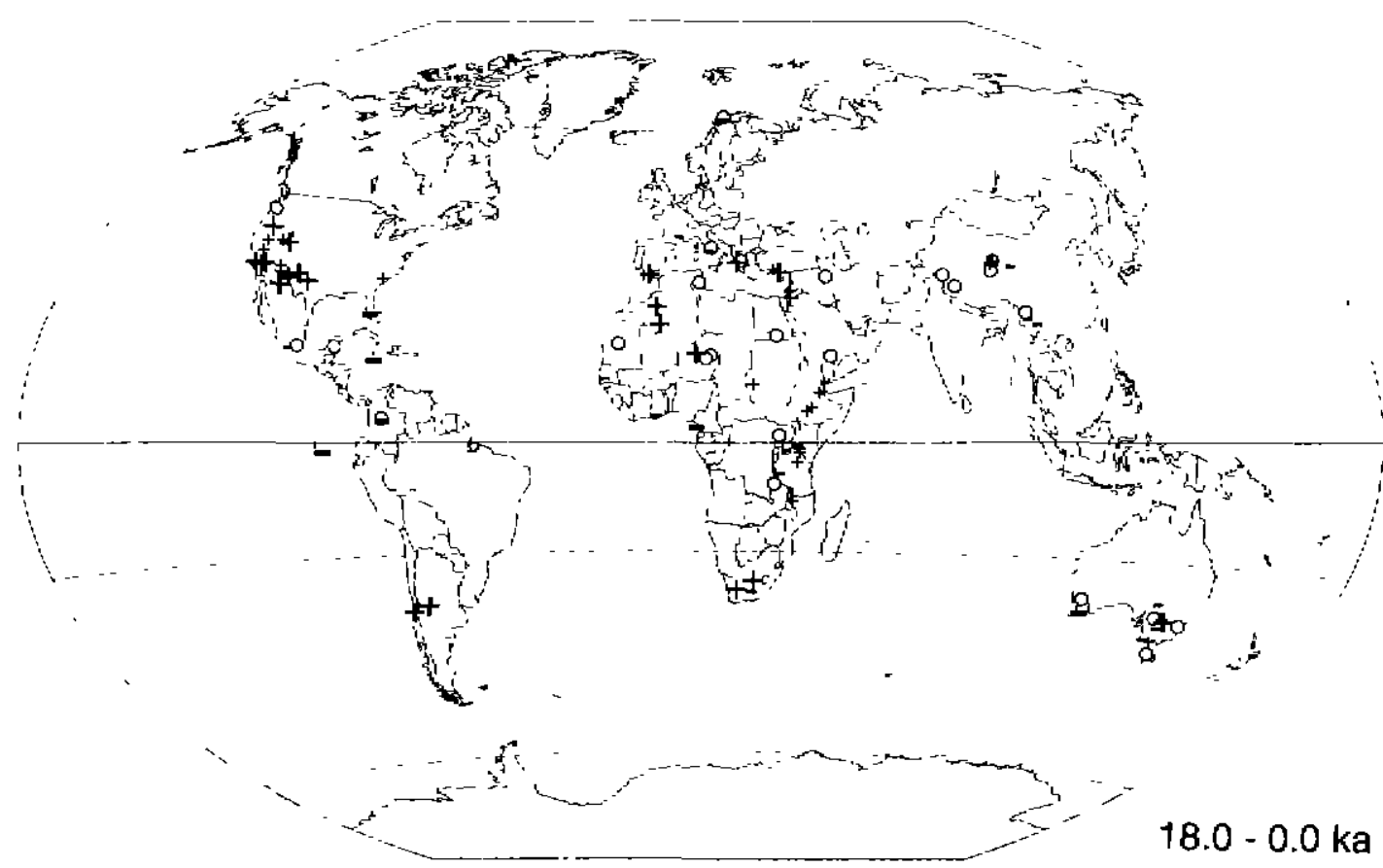

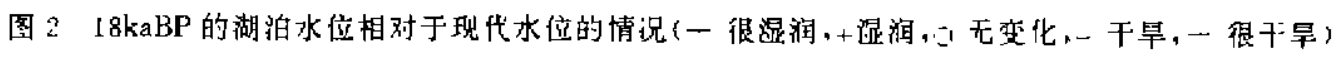

Fig. I The difference of lake status between $18 \mathrm{kaBP}$ and $0 \mathrm{kaBP}$

+ very wetter, - wecter, li no change, - drier, - very drier 
现代干. 而中、低纬地区、从总体而言.比现在湿润. 如在北美西南部. 现今是一片干旱地区、但 $18 \mathrm{kaBP}$ 时湖水位显著比今高,表示当时气候较今湿酒; 在地中海地区以及撤哈拉与萨西尔地 区.少量的湖泊点位同样显示较今湿润，而在赤道地区、从中美洲一直到非洲. 均以干旱为主、 但在东非大裂谷周围、湖泊资料显示较分湿润。此外、在南半球中纬度地区即从南美洲至南涟 大利亚.呈现一条明显的东西向的湿润带. 但在亚洲中部.湖泊资料显示的湿润变化不甚洁 楚, 闭能与这些点位受到了某些非气候因子影响有关、如冰川融水补给。

$15 \mathrm{kaBP}$ 的湖泊资料反映全球水汽状况与 $18 \mathrm{kaBP}$ 没有太大的区别 (图 3)、说明其大范围 的气候格局尚无大的变动. 但环地中海地区高湖面的湖泊数量较 $18 \mathrm{kaBP}$ 有些减少, 尽管一部 分湖泊点位反映当时的环境仍较今湿湖。但说明气候条件逐渐趋于干旱. 在撒哈拉及萨西尔以 及亚洲季风区的湖泊、湖水位达到了最高点.但部分来自中国西部的点位值得怀疑. 因为.这些 点子由于海拨较高、很可能受冰期冰融水的影响,但从非洲与亚洲的湖泊变化来看.至少在这 两个地区的季风较 $18 \mathrm{kaBP}$ 有增强的迹象. 相比较而言.其它地区没有太大的变化.

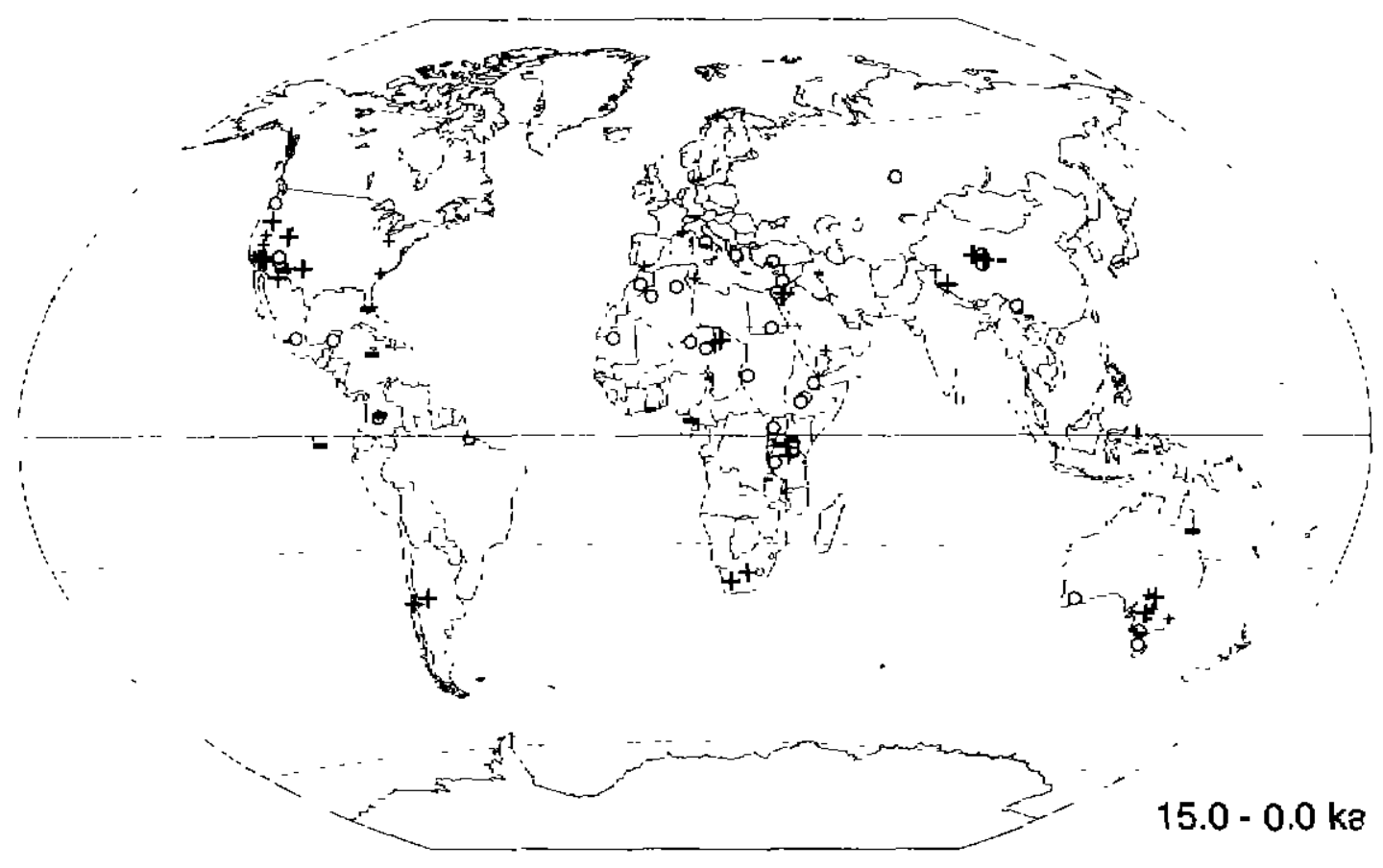

图 $315 \mathrm{kaBP}$ 的湖泊水位根对于现代水位的情况(说明同图 2)

Fig. 3 The difference of lake status between 15 kaBP and B kaBP. explanations see in Fig. "2

$12 \mathrm{kaBP}$ 较之 $18 \mathrm{kaBP}$ 及 $15 \mathrm{kaBP}$ 由于有记录的点位增加了。变化的模式也显得较清㪿《图 4). 需要注意的是当时北美及欧洲北部两个冰盖已显著收缩. 分布在欧洲高纬地区一些湖泊显 方这些地区气候偏干,这种偏干的气候与冰盖存在有关. 在北半球中纬地带即北美与欧洲中部 及中亚等地、湖泊筫料显示该带内气候较今湿湖、但北缘开始偏干、呈现一种湿润的气候环境 问北移动的趋势. 而在非洲大陆的湖泊点位显示该时期风开始增强.湖水位上升. 在南半球 中纬地带、在 $18 \mathrm{kaBP}$ 及 $15 \mathrm{kaBP}$ 中出现的湿润带已移出该地区、代之与今相近似的湿润条件. 


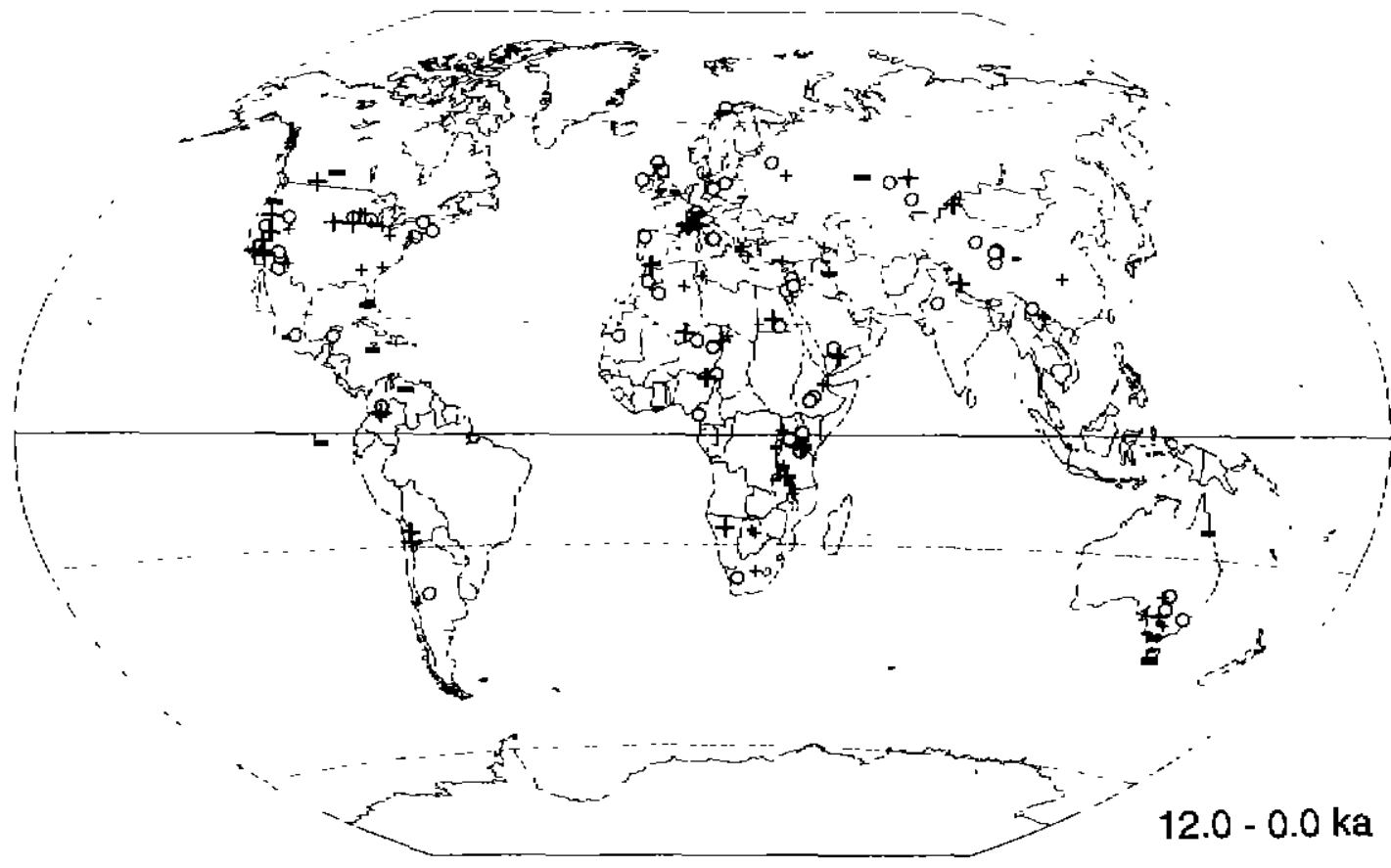

图 $412 \mathrm{kaBP}$ 的湖泊水位相对于现代水位的情况（说明同图 2）

Fig. 4 The difference of lake status between $12 \mathrm{kaBP}$ and $0 \mathrm{kaBP}$, explanations see in Fig. \&

到 9kaBP 时, 湖泊资料显示了一种与以前完全不同的湿润模式(图 5)。一个突出的例子就 是非洲大陆及亚洲大部分地区湖泊水位显著高于现在. 而这两个地区正是目前季风盛行地区. 在北美大陆,随着冰盖的消失,西风带的北移,使得北美大陆的中部气候变干, 湖水位下降、与 此同时.受季风影响的北美西南部由于季风的加强弥补因西风带北移造成的水深来源的缄少， 从而仍然维持部分湖泊的高湖面. 在欧洲大陆的南部与北部气侯均较现代湿润, 但欧洲中部及 波罗的海南部地区气候偏干.在中亚及东亚北部, 部分湖泊资料亦显示气候较今干旱. 此外南 半球已有的部分记录显示该时期水厺条件与当今相差不大.空间分布上没有临著的干湿变化.

最后一个时段是 $6 \mathrm{kaBP}$. 从图 6 可以看出.当时全球的湿润状况与 $9 \mathrm{kaBP}$ 基本相侧. 所不 同的是在北美大陆湖泊资料显示湿湖条件较 $9 \mathrm{kaBP}$ 更为干旱,原先在北美西南部的一些高湖 面均转为中、低水位.与现在相似. 但在中亚地区.湖泊指示的湿润条件较之 $9 k a B P$ 有所加强. 此外南半球中纬地带及澳洲大陆南部, 湖泊资料指示该地区的湿润条件较 $9 \mathrm{kaBP}$ 有了较大的 改善.

综上所述,自末次冰盛期以来,北美大陆的湖泊资料指示的是由湿变干的过程,而在非洲 及亚洲季风区、湖泊资料指示的是水汽条件基本上是由干变湿的讨程. 由于在冰期时.北美与 欧洲北部发育了两个巨大的冰盖, 从而使冰盖南络地区受反气旋的东风气流的控制、气候干 燥. 但由于位于该地区的湖泊点位较少。因此反映得不够明显. 在中低纬度地区.由于冰盖存在 导致的北半球西风带南移.使得北美洲的中部及地中海的北部等地区、气侯远比今湿闻 ${ }^{[n] . ~}$

需要注意的是由于冰期的寒滛气候, 使得蒸发量显著减少.从而使季风地区的湖沁在降水 


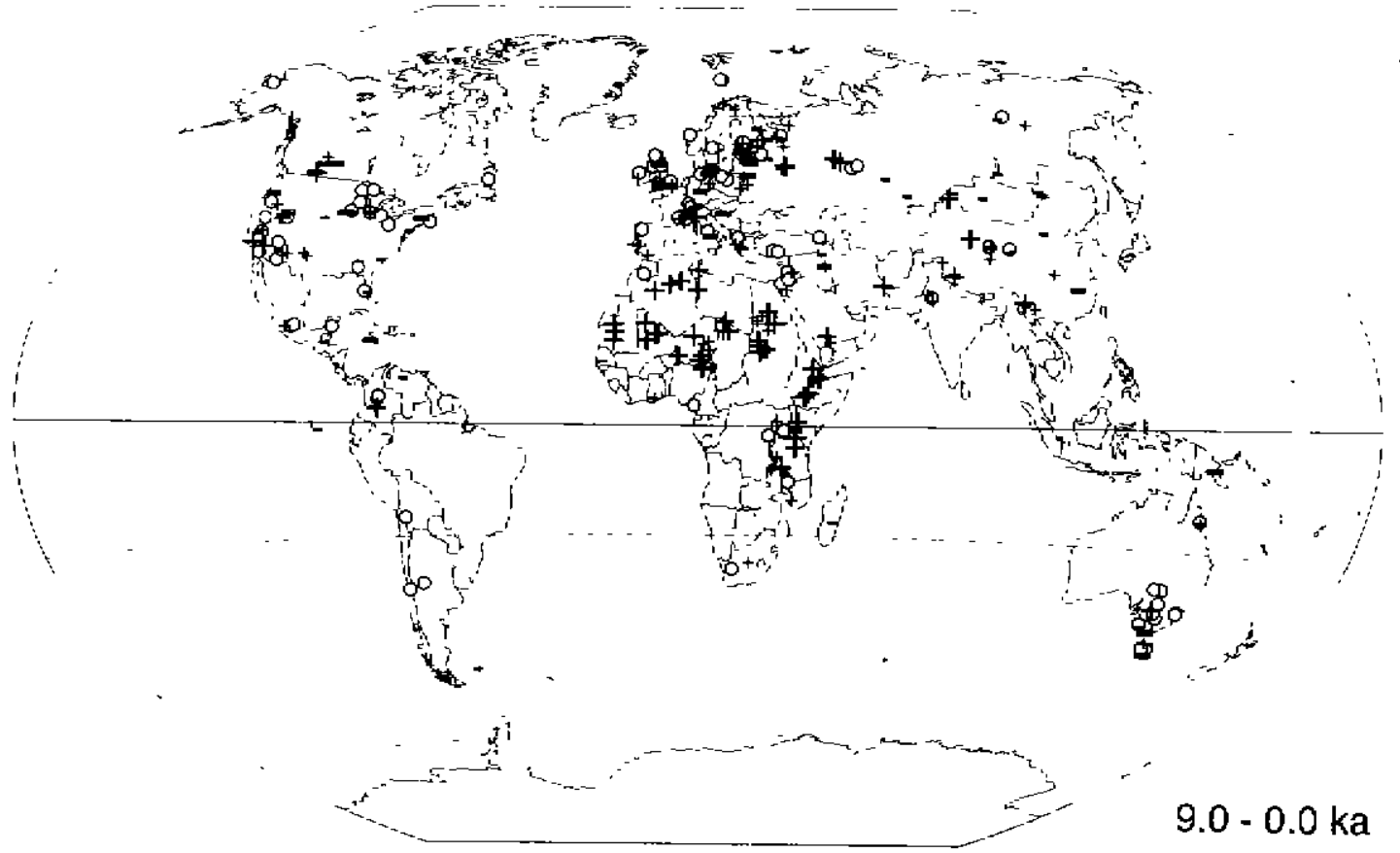

图 $59 \mathrm{kaBP}$ 的湖活水位相对于现代本位的晴况（说明同图 2)

Fig. 5 The difference of lake stans brrwect $\mathrm{kaBP}$ and 0 kaBP, explanations set in Fig. 2

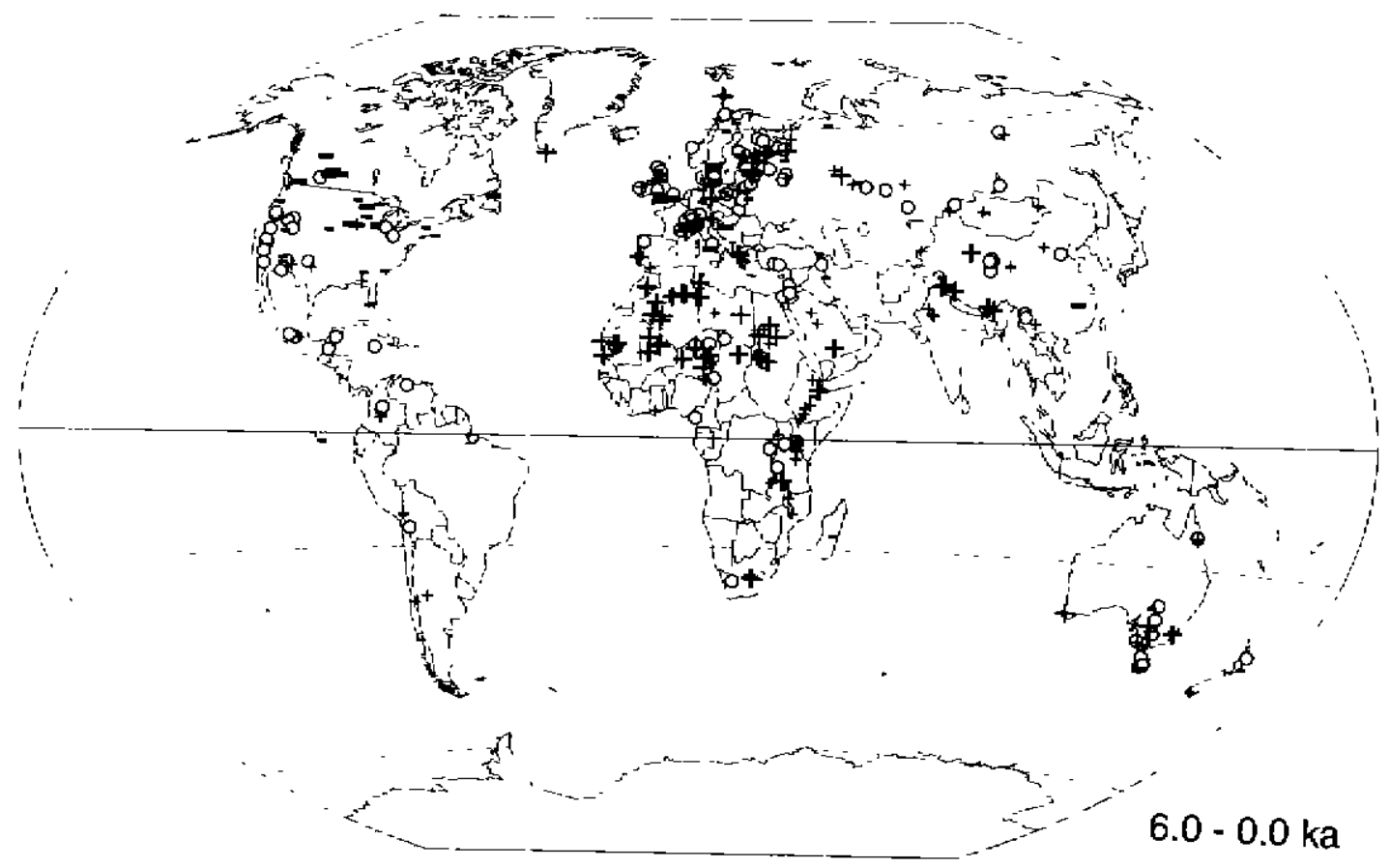

图 $66 \mathrm{kaBP}$ 的湖泊水位相对于现代水位的情况(说明同图 2)

Fig. $f$ The diflerence of lake status between $6 \mathrm{kaBP}$ and $0 \mathrm{kaBP}$. explanations see in Fig. 2 


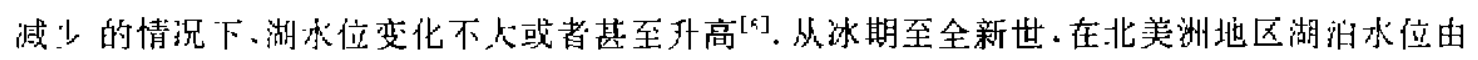
高转低.其转折点大约在早全新世.而直至 $6 \mathrm{kaBP}$ 才出现稳定一致的低水位状况、在季风区、 从 $12 \mathrm{k} a \mathrm{BP}$ 幵始出现湖水位大幅度上涨的情况.直至 $9 \mathrm{kaBP}$ 时已基本达到稳定与一致的情况. 较北美洲湖泊变化提前数千年. 季风区湖泊在 $9 \mathrm{kaBP}$ 及 $6 \mathrm{kaBP}$ 时高湖面是由北半球夏季太阳 辐射增加导致的. 增加的太阳辐射加剧了海陆温差、使吹向陆地的编南气流得以加强.带来了 大量的降水。使湖面升高 ${ }^{[?]}$. 但随着中全新世后.夏季太阳辐射的减少, 季风减弱而湖水位亦开 始下降.

\section{3 结论}

（1）现代湖泊水位与古时相比, 以中低纬度偏低而高纬度地区偏湿,这种分布与全球湿润 条件分布的状况是一致的.

（2）自末次盛冰期以来, 北美大陆中部及南部的湿润犹况是随着冰盖的消融、西风带的往 北䚾移而寀渐变干的.

(3) 季风区的湖泊变化所指示的湿润条件基本上祫期偏干而暖期偏湿. 但前者由于温度 下降及蒸发减小而抵消, 后者由于北半球太阳辐射增加造成的海陆温差加大、季风增强所致. 伴随着中全新世以后夏季太阳辐射减弱、季风开始萎缩、湖泊水位又开始下降、

致谢本项工作是作者在瑞典隆鿵大学自然地理系古气候动力学研究小组访问期间完 成的，方金琪博士提供了中国湖泊数据本。特此致谢。

\section{参 考 文 䏻}

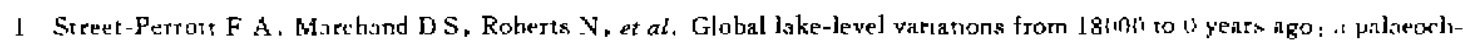

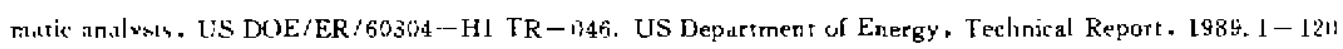

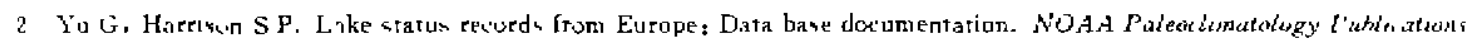
Sereer Repuit, 1995, 3: 1-451

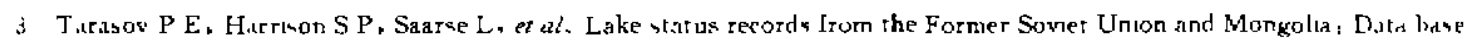
durumentiation. NOAA Paleckimuluiugy Puhlicatums Series Repurt, 1994, 2: 1-:219

4 F ing J:nq. Lake rvolution durng the past 300 us years in China, and its implications for environ:mental rhange. Wiuternury Researci, 1981, 36:37-6n

5 Weh T, A glabil paleoclinatic data b.se for $600 \mathrm{yr}$ BP. ES Department of Energy Technical Report, 1985, 18: 1-155

6 Qin Iroqlang. Yu Ge. The implications of lake level varations at $6 \mathrm{ka}$ and $18 \mathrm{kal}$ in inland mainland Asta. Grofide and Fantary (hange. 1997in press)

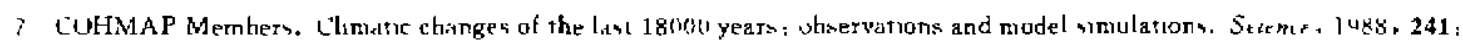
$11343-135,2$ 


\title{
THE GEOLOGICAL EVIDENCE OF THE GLOBAL MOISTURE CONDITION CHANGES SINCE THE LAST GLACIAL MAXIMUM: THE CONSTRUCTION OF GLOBAL LAKE STATUS DATA BASE \&. THE SYNTHESIS IN THE LARGE SPATIO-TEMPORAL SCALE
}

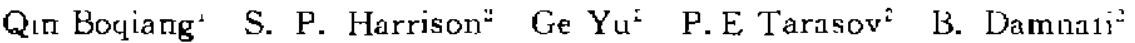

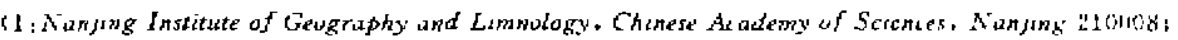 \\ 2: Dypumics Palacurlimatalog3. Granp, Lund (innersity, Lund, Stueden]
}

\begin{abstract}
The construction of global lake status data base has been introduced in this paper. This is a geological evidence-based semi-quantıtative lake level data set. It consists of 6 regional lake status data sets, i. e. Oxford Lake Level Data Base. European Lake Status Data Base. Former Sov1et Unıon and Mongolian Data Base. Updated African Lake Status Data Base and Chunese Lake Level Data Base. With uniform criteria, these sub-data-sets are incorporated into the Global Lake Status Data Base. The lake status record from the Global Lake Status Data Base essentially reflect the coherent patterns of changes in moisture condirion in the spatio-temporal scale since the last glacial maximum. In the present, lakes from low and mid-latıtudes are characterised by lower status whereas the lakes in high latitudes rrgisier higher lake status. From the Last Glacier Maximum to the middle Holocene. the laken from North America register high in cool period to low in Holocene. indicating the changes in mossture condition from wetter to drier. The culminating dry period occurs in mid-Holucene. This change pattern of moisture condition is associated with the shift of westerlies reli1ed in the presence and non-presence of ice sheet in the North America. In the Afro Asia monsmonal sector. the lake status are characterised by lower in the cool period and higher in warm yerind. particularly in the early Holocene. The higher lake status from monsoonal seitor in early Holocene maintained until mid-Holocene is strongly linked with the increase in summer insolation in Northern Hemisphere. It . therefore. enhances the contrast of land-ocenn thermal property. produces the strengthened monsoonal stream jet. The moisture condition changes in the mid-latitude in northern Hemisphere. including the midst of N. Americal and curcum-Mediterranean + are related to the presence of sce sheet in the north and the displice. ment of the westerlies. But the lake status records in Central Asia show that the culmination of wetter condition appears in the middle Holocene rather than in the early Holocene, which indiactes that the enhanced summer monsoon started to prevail in the low-latitudinal areas in the early Holocence, then gradually expanded northward to experience in the mid-latitude in the middle Holocene.
\end{abstract}

Key Words Global Lake Data Base. lake status reco-d. spatio-temporal an alysıs 